\title{
Corrosion Inhibition Effect of Carbon Steel in Sea Water by L-Arginine- $\mathrm{Zn}^{2+}$ System
}

\author{
S. Gowri, ${ }^{1}$ J. Sathiyabama, ${ }^{1}$ and S. Rajendran ${ }^{1,2}$ \\ ${ }^{1}$ PG and Research Department of Chemistry, Corrosion Research Centre, GTN Arts College, Dindigul, Tamil Nadu 624 005, India \\ ${ }^{2}$ Department of Chemistry, RVS School of Engineering and Technology, Dindigul, Tamil Nadu, India
}

Correspondence should be addressed to S. Gowri; brigow@yahoo.co.in

Received 17 November 2013; Accepted 7 January 2014; Published 15 April 2014

Academic Editor: Evangelos Tsotsas

Copyright (c) 2014 S. Gowri et al. This is an open access article distributed under the Creative Commons Attribution License, which permits unrestricted use, distribution, and reproduction in any medium, provided the original work is properly cited.

\begin{abstract}
The inhibition efficiency of L-Arginine- $\mathrm{Zn}^{2+}$ system in controlling corrosion of carbon steel in sea water has been evaluated by the weight-loss method. The formulation consisting of $250 \mathrm{ppm}$ of L-Arginine and $25 \mathrm{ppm}$ of $\mathrm{Zn}^{2+}$ has $91 \%$ IE. A synergistic effect exists between $\mathrm{L}$-Arginine and $\mathrm{Zn}^{2+}$. Polarization study reveals that the L-Arginine- $\mathrm{Zn}^{2+}$ system functions as an anodic inhibitor and the formulation controls the anodic reaction predominantly. AC impedance spectra reveal that protective film is formed on the metal surface. Cyclic voltammetry study reveals that the protective film is more compact and stable even in a $3.5 \% \mathrm{NaCl}$ environment. The nature of the protective film on a metal surface has been analyzed by FTIR, SEM, and AFM analysis.
\end{abstract}

\section{Introduction}

Corrosion is an economic problem worldwide. Corrosion can damage the materials which are used to construct automobiles, pipeline systems (water, oil), bridges and buildings, petroleum refineries, and so forth [1]. Corrosion inhibitors have long been used for the daily operation of recirculating cooling water system, industrial acid cleaning, oil well acidification, and descaling due to their economical and efficient properties [2-4]. Most of these organic compounds contain nitrogen, sulphur, oxygen, and multiple bonds in the molecules which are adsorbed on the metal surface and the organic compound $[5,6]$. Amino acids are nontoxic, relatively cheap, and easy to produce with purities greater than $99 \%$. Recently, with respect to amino acid as corrosion inhibitor, many achievements have been gained in laboratory studies [7-10].

The literature presents some studies involving amino acids on the corrosion prevention of mild steel [11], aluminium [12], and copper [13]. Naturally occurring organic substances as corrosion inhibitors for mild steel in acid have been investigated. The potentiodynamic cathodic and anodic polarization technique was used to study the effect of some common amino acids concentration on the corrosion inhibition of mild steel in $\mathrm{H}_{2} \mathrm{O}_{2}$ [14]. In general, amino acids with longer hydrocarbon chains showed greater inhibition. Additional amino group or groups which increased electron density on the alpha amino group also increased the inhibition efficiency [15].

Molecular Structure of L-Arginine<smiles>N=C(N)NCCCC(N)C(=O)O</smiles>

2-Amino-5-guanidinopentanoic acid

The present work undertakes the following.

(1) To evaluate the inhibition efficiency of L-Arginine $\mathrm{Zn}^{2+}$ system in controlling corrosion of carbon steel immersed in the absence and presence of $\mathrm{Zn}^{2+}$ by weight- loss method.

(2) To investigate the mechanistic aspects of corrosion inhibition by electrochemical studies like polarization study. 
(3) To analyses the protective film by FTIR, SEM, and AFM.

\section{Materials and Methods}

\subsection{Experimental}

2.1.1. Preparation of Specimen. Carbon steel specimens ( 0 . $0267 \% \mathrm{~S}, 0.06 \% \mathrm{P}, 0.4 \% \mathrm{Mn}, 0.1 \% \mathrm{C}$, and the rest iron) of dimensions $1.0 \mathrm{~cm} \times 4.0 \mathrm{~cm} \times 0.2 \mathrm{~cm}$ were polished to a mirror finish and degreased with trichloroethylene.

2.2. Weight-Loss Method. Carbon steel specimens in triplicate were immersed in $100 \mathrm{~mL}$ of the sea water containing various concentrations of the inhibitor in the presence and absence of $\mathrm{Zn}^{2+}$ for one day. The weight of the specimens before and after immersion was determined using a Shimadzu balance, model AY62. The corrosion products were cleansed with Clarke's solution [16]. The inhibition efficiency (IE) was then calculated using the equation

$$
\mathrm{IE}=100\left[1-\left(\frac{W_{2}}{W_{1}}\right)\right] \%,
$$

where $W_{1}=$ corrosion rate in the absence of the inhibitor and $W_{2}=$ corrosion rate in the presence of the inhibitor.

2.3. Potentiodynamic Polarization. Polarization studies were carried out in a CHI-electrochemical work station with impedance model 660A. It was provided with $\mathrm{iR}$ compensation facility. A three-electrode cell assembly was used. The working electrode was carbon steel. A saturated calomel electrode was the reference electrode. Platinum was the counter electrode. From the polarization study, corrosion parameters such as corrosion potential $\left(E_{\text {corr }}\right)$, corrosion current $\left(I_{\text {corr }}\right)$, Tafel slopes anodic $=b_{a}$ and cathodic $=b_{c}$, and LPR value. The scan rate $(V / S)$ was 0.01 . Hold time at (Efcs) was zero and quiet time (s) was two.

2.4. AC Impedance Spectra. The instrument used for polarization study was used to record AC impedance spectra also. The cell setup was also the same. The real part $\left(Z^{\prime}\right)$ and imaginary part $\left(Z^{\prime \prime}\right)$ of the cell impedance were measured in ohms at various frequencies. Values of charge transfer resistance $\left(R_{t}\right)$ and the double layer capacitance $\left(C_{\mathrm{dl}}\right)$ were calculated. AC impedance spectra were recorded with initial $E(v)=0$, high frequency $(\mathrm{Hz})=1 \times 10^{5}$, low frequency $(\mathrm{Hz})=$ 1 , amplitude $(\mathrm{V})=0.005$, and quiet time $(\mathrm{s})=2$.

2.5. Surface Examination Study. The carbon steel specimens were immersed in various test solutions for a period of 1 day. After 1 day, the specimens were taken out and dried. The nature of the film formed on the surface of the metal specimen was analyzed by various surface analysis techniques.

2.6. FTIR Spectra. The film formed on the metal surface was carefully removed and mixed thoroughly with $\mathrm{KBr}$. The FTIR spectra were recorded in a Perkin Elmer 1600 spectrophotometer.
TABle 1: Physicoparameters of sea water (Ramnad, Tamil Nadu, India).

\begin{tabular}{lc}
\hline Parameters & Results \\
\hline Total dissolved solid & $50787 \mathrm{ppm}$ \\
Electrical conductivity & $74687 \mathrm{mics} / \mathrm{cm}$ \\
$\mathrm{pH}$ & 8.14 \\
Total hardness as $\mathrm{CaCo}_{3}$ & $11500 \mathrm{ppm}$ \\
Calcium & $1400 \mathrm{ppm}$ \\
Magnesium & $1920 \mathrm{ppm}$ \\
Chloride & $25750 \mathrm{ppm}$ \\
Sulphate & $1033 \mathrm{ppm}$ \\
\hline
\end{tabular}

2.7. Scanning Electron Microscopic Studies (SEM). The carbon steel immersed in blank solution and in the inhibitor solution for a period of one day was removed, rinsed with double distilled water, dried, and observed in a scanning electron microscope to examine the surface morphology. The surface morphology measurements of carbon steel were examined using JEOLMODEL6390 computer controlled scanning electron microscope.

2.8. Atomic Force Microscopy Characterization (AFM). The carbon steel specimen immersed in blank and in the inhibitor solution for a period of one day was removed, rinsed with double distilled water, dried, and subjected to the surface examination. Atomic force microscopy (Veeco Innova model) was used to observe the samples' surface in tapping mode, using cantilever with linear tips. The scanning area in the images was $5 \mu \mathrm{m} \times 5 \mu \mathrm{m}$ and the scan rate was $0.6 \mathrm{HZ}$ / second.

2.9. Cyclic Voltammetry. Cyclic voltammograms were recorded in a VersaSTAT MC electrochemical system. A threeelectrode cell assembly was used. The working electrode was carbon steel. The exposed surface area was $1 \mathrm{~cm}^{2}$. A saturated calomel electrode (SCE) was used as the reference electrode and a rectangular platinum foil was used as the counter electrode. The cyclic voltammetry curves were recorded in the scan range of -1.8 to $-1.8 \mathrm{~V}$ (SCE) with a scan rate of $20 \mathrm{mV} \mathrm{s}^{-1}$.

\section{Results and Discussion}

3.1. Analysis of Weight-Loss Study. The physicochemical parameters of sea water are given in Table 1 . The corrosion inhibition efficiencies of L-Arginine- $\mathrm{Zn}^{2+}$ systems are given in Table 2 .

Inhibition efficiencies (IE) and corrosion rates (CR) of carbon steel immersed in sea water in the absence and presence of inhibitors (L-Arginine and $\mathrm{Zn}^{2+}$ system).

The calculated corrosion inhibition efficiency (IE) and corrosion rates (CR) of L-Arginine in controlling corrosion of carbon steel in sea water for a period of one day in absence and presence of zinc ion are given in Table 2. It is observed from Table 2 that the calculated value indicates the ability of L-Arginine to be a good inhibitor. The IE is found to be 
TABLE 2: Inhibition efficiencies (IE) and corrosion rates (CR) obtained from L-Arginine- $\mathrm{Zn}^{2+}$ systems, when the carbon steel was immersed in sea water.

\begin{tabular}{lcccc}
\hline L-Arginine $(\mathrm{ppm})$ & $\begin{array}{c}\mathrm{Zn}^{2+}(0 \mathrm{ppm}) \\
\text { IE\% }\end{array}$ & $\begin{array}{c}\mathrm{Zn}^{2+}(25 \mathrm{ppm}) \\
\text { CR mmpy }\end{array}$ & IE\% & CR mmpy \\
\hline 0 & - & 0.1809 & 64 & 0.0651 \\
50 & 26 & 0.1339 & 69 & 0.0561 \\
100 & 32 & 0.1230 & 72 & 0.0507 \\
150 & 38 & 0.1122 & 79 & 0.0379 \\
200 & 40 & 0.1085 & 85 & 0.0271 \\
250 & 44 & 0.1013 & 91 & 0.0163 \\
\hline
\end{tabular}

enhanced in the presence of $\mathrm{Zn}^{2+}$ ion. L-Arginine alone shows some inhibition efficiencies. 50 ppm of Arginine shows $26 \%$ of IE, as the concentration of L-Arginine increases, the IE also increases. A synergistic effect exists between LArginine and $\mathrm{Zn}^{2+}$. For example, $25 \mathrm{ppm}$ of $\mathrm{Zn}^{2+}$ has 64 percent IE; $250 \mathrm{ppm}$ of Arg has 44 percent IE. Interestingly, their combination has high IE, namely, 91\%.

Therefore the mixture of inhibitors shows better IE than the individual inhibitors. In the presence of $\mathrm{Zn}^{2+}$, a large amount of L-Arginine is transported towards the metal surface. $\mathrm{Fe}^{2+}$-L-Arginine complex is formed on the anodic sites of the metal surface. Thus, the anodic reaction is controlled. The cathodic reaction is the generation of $\mathrm{OH}^{-}$, which is controlled by the formation of $\mathrm{Zn}(\mathrm{OH})_{2}$ on the cathodic sites of the metal surface. Thus, the anodic reaction and cathodic reaction are controlled effectively. This accounts for the synergistic effect existing between $\mathrm{Zn}^{2+}$ and L-Arginine. [17, 18].

3.2. Synergism Parameter. Synergism parameter $\left(S_{I}\right)$ has been used to know the synergistic effect existing between two inhibitors. The synergism parameter $\left(S_{I}\right)$ can be calculated using the following relationship:

$$
S_{I}=\frac{1-\theta_{1+2}}{1-\theta_{1+2}^{\prime}},
$$

where $\theta_{1+2}=\left(\theta_{1}+\theta_{2}\right)-\left(\theta_{1} \times \theta_{2}\right), \theta_{1}=$ surface coverage of inhibitor L-Arginine, $\theta_{2}$ = surface coverage by inhibitor zinc, and $\theta_{1+2}^{\prime}=$ combined surface coverage of inhibitors (LArginine + Zinc), where surface coverage $\theta=$ IE/ 100 .

$S_{I}$ value is found to be greater than one suggesting the existence of a synergistic effect between the inhibitors. The calculated value of synergism parameters are given in Table 3. For different concentrations of inhibitors, $S_{I}$ approaches 1 , where no interaction between the inhibitor compounds exists. When $S_{I}>1$, it points to a synergistic effect. In the case of $S_{I}<1$ the negative interaction of the inhibitor prevails (i.e., corrosion rate increases). From Table 3 it can be seen that the value of synergism parameter $\left(S_{I}\right)$ for the formulation consisting of $250 \mathrm{ppm}$ of L-Arginine and $25 \mathrm{ppm}$ of $\mathrm{Zn}^{2+}$ is greater than one. Thus, the enhancement of the inhibition efficiency caused by the addition of $\mathrm{Zn}^{2+}$ to L-Arginine is due to the synergistic effect $[19,20]$.
TABLE 3: Synergism parameter $\left(S_{I}\right)$ for carbon steel immersed in sea water in the absence and presence of inhibitors.

\begin{tabular}{lcccc}
\hline L-Arginine $(\mathrm{ppm})$ & $\theta_{1}$ & $\theta_{2}\left(\mathrm{Zn}^{2+}-25 \mathrm{ppm}\right)$ & $\theta_{1+2}^{\prime}$ & $S_{I}$ \\
\hline 50 & 0.26 & 0.64 & 0.69 & 0.8594 \\
100 & 0.32 & 0.64 & 0.72 & 0.8743 \\
150 & 0.38 & 0.64 & 0.79 & 0.88 \\
200 & 0.40 & 0.64 & 0.85 & 1.44 \\
250 & 0.44 & 0.64 & 0.91 & 1.76 \\
\hline
\end{tabular}

3.3. Analysis of Variance (F-Test). F-Test was carried out to investigate whether the synergistic effect existing between inhibitors systems is statistically significant. If $F$-value is above 5.32 for 1, 8 degrees of freedom, it was statistically significant. It is below the value of 5.32 for 1,8 degrees of freedom, it was statistically insignificant at 0.05 level of significant confirmed. The results are given in Table 4 ; the results of analysis of variance show the influence of $25 \mathrm{ppm}$ of $\mathrm{Zn}^{2+}$ on the inhibition efficiencies of $50 \mathrm{ppm}, 100 \mathrm{ppm}, 150 \mathrm{ppm}$, $200 \mathrm{ppm}$, and $250 \mathrm{ppm}$ [21].

The obtained $F$-value 13.808 for 25 ppm of zinc was statistically significant, since it was greater than the critical $F$-value 5.32 for 1,8 degrees of freedom at 0.05 level of significance. Therefore, it is concluded that the influence of $25 \mathrm{ppm} \mathrm{Zn}^{2+}$ on the inhibition efficiencies of various concentrations of LArginine is statistically significant.

3.4. Analysis of Polarization Curves of Arginine $\mathrm{Zn}^{2+}$. Polarization studies have been used to study the formation of protective film on the metal surface. The potentiodynamic polarization curves of carbon steel immersed in various test solutions are shown in Figure 1. The corrosion parameters are given in Table 5.

When carbon steel is immersed in the sea water the corrosion potential is $-784 \mathrm{mV}$ versus SCE. The inhibitor system shifts the corrosion potential to $-758 \mathrm{mV}$ versus SCE. This indicates that the anodic reaction is controlled predominantly. The corrosion current value and the LPR value for sea water are $7.042 \times 10^{-6} \mathrm{~A} / \mathrm{cm}^{2}$ and $5.375 \times 10^{3} \Omega \mathrm{cm}^{2}$. In the presence of inhibitors, the corrosion current value decreases to $6.133 \times 10^{-6} \mathrm{~A} / \mathrm{cm}^{2}$ and the LPR value has increased to $6.185 \times 10^{3} \Omega \mathrm{cm}^{2}$. This indicates that a protective film formed on the metal surface. [22-28].

3.5. Analysis of AC Impedance Spectra for L-Arginine- $\mathrm{Zn}^{2+}$ System. AC impedance spectra have been used to detect the formation film on the metal surface. The AC impedance spectra of carbon steel immersed in sea water in the absence and presences of inhibitors are shown in Figure 2. The impedance parameters such as charge transfer resistance $\left(R_{t}\right)$ and double layer capacitance $\left(C_{\mathrm{dl}}\right)$ values are given in Table 6 .

From Table 6 the $R_{t}$ value is $120.22 \Omega \mathrm{cm}^{2}$ and $C_{\mathrm{dl}}$ value is $4.242 \times 10^{-8} \mathrm{~F} / \mathrm{cm}^{2}$. When L-Arg and $\mathrm{Zn}^{2+}$ are added to sea water, $R_{t}$ value increases from $120.22 \Omega \mathrm{cm}^{2}$ to $142.09 \Omega \mathrm{cm}^{2}$. The $C_{\mathrm{dl}}$ value decreases from $4.242 \times 10^{-8} \mathrm{~F} / \mathrm{cm}^{2}$ to $3.589 \times$ $10^{-8} \mathrm{~F} / \mathrm{cm}^{2}$. This confirms the formation of protective film on 
TABLE 4: Distribution of $F$-value between inhibition efficiencies of various concentrations of L-Arginine $\mathrm{Zn}^{2+}$.

\begin{tabular}{lcccccc}
\hline $\mathrm{Zn}^{2+} \mathrm{ppm}$ & Source of variance & Sum of squares & Degrees of freedom & Mean square & $F$ & Level of significance \\
\hline \multirow{2}{*}{25} & Between & 933.12 & 1 & 933.12 & \multirow{2}{*}{13.808} & $P>0.05$ \\
& Within & 540.6 & 8 & 67.575 & & \\
\hline
\end{tabular}

TABLE 5: Corrosion parameters of carbon steel immersed in sea water in the absence and presence of inhibitors obtained by polarization method.

\begin{tabular}{|c|c|c|c|c|c|c|}
\hline L-Arg ppm & $\mathrm{Zn}^{2+} \mathrm{ppm}$ & $E_{\text {corr }} \mathrm{mV}$ versus SCE & $I_{\text {corr }} \mathrm{Acm}^{-2}$ & $b_{a} \mathrm{mV} \mathrm{decade}{ }^{-1}$ & $b_{c} \mathrm{mV} \mathrm{decade}{ }^{-1}$ & $\mathrm{LPR} \Omega \mathrm{cm}^{2}$ \\
\hline 0 & 0 & -784 & $7.042 \times 10^{-6}$ & 232 & 139 & $5.375 \times 10^{3}$ \\
\hline 250 & 25 & -758 & $6.133 \times 10^{-6}$ & 207 & 151 & $6.185 \times 10^{3}$ \\
\hline
\end{tabular}

TABLE 6: Impedance parameters of carbon steel immersed in sea water in the absence and presence of inhibitors obtained by AC impedance spectra.

\begin{tabular}{lccc}
\hline $\mathrm{L}-A r g \mathrm{ppm}$ & $\mathrm{Zn}^{2+} \mathrm{ppm}$ & $R_{t} \Omega \mathrm{cm}^{2}$ & $C_{\mathrm{dl}} \mathrm{F} / \mathrm{cm}^{2}$ \\
\hline 0 & 0 & 120.22 & $4.242 \times 10^{-8}$ \\
250 & 25 & 142.09 & $3.589 \times 10^{-8}$ \\
\hline
\end{tabular}

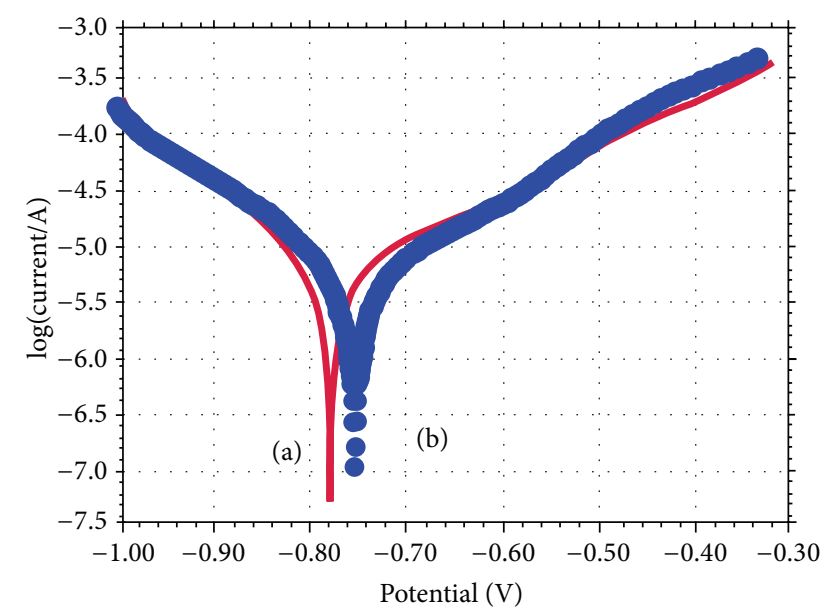

FIgURE 1: Polarization curves of carbon steel immersed in various test solutions. (a) Sea water. (b) Sea water $+250 \mathrm{ppm}$ of L-Arg + $25 \mathrm{ppm}$ of $\mathrm{Zn}^{2+}$.

the metal surface. This accounts for the very high IE of L-Arg$\mathrm{Zn}^{2+}$ system.

3.6. Analysis of FTIR Spectra. FTIR spectrometer is a power instrument that is used to determine the type of bonding for organic inhibitors adsorbed on the metal surface. FTIR spectra have been used to analyze the protective film formed on the metal surface. TheFTIR spectrum of pure L-Arg is given in Figure 3(a).

The CN stretching frequency appears at $1130 \mathrm{~cm}^{-1}$. The $\mathrm{C}=\mathrm{O}$ stretching frequency of carboxyl group appears at $1689 \mathrm{~cm}^{-1}$. The $\mathrm{NH}$ stretching frequency appears at $3290 \mathrm{~cm}^{-1}$. The FTIR spectrum of the film formed on the metal surface after immersion in the sea water for 1 day containing $250 \mathrm{ppm}$ of L-Arg and $25 \mathrm{ppm}$ of $\mathrm{Zn}^{2+}$ is shown in

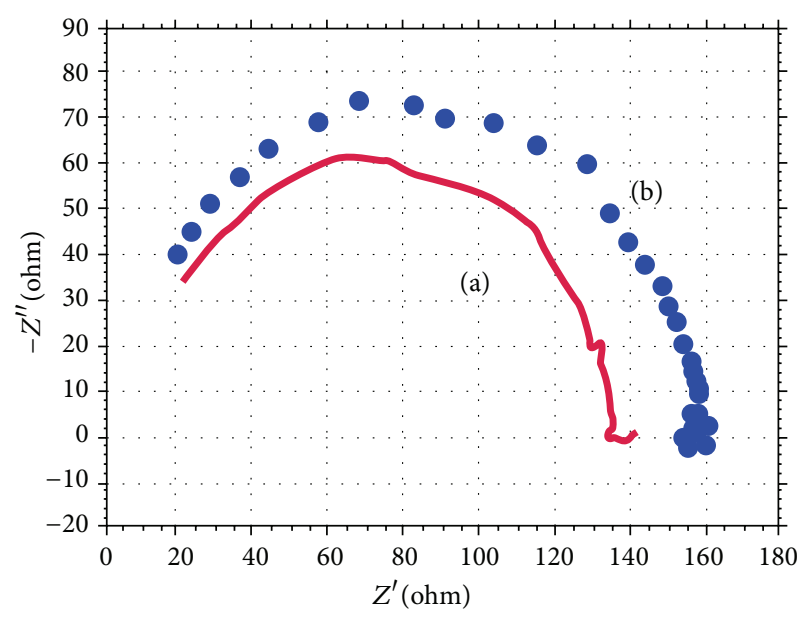

FIGURE 2: AC impedance spectra of carbon steel immersed in various test solutions (Nyquist plots). (a) Sea water. (b) Sea water + $\mathrm{L}-\operatorname{Arg}(250 \mathrm{ppm})+\mathrm{Zn}^{2+}(25 \mathrm{ppm})$.

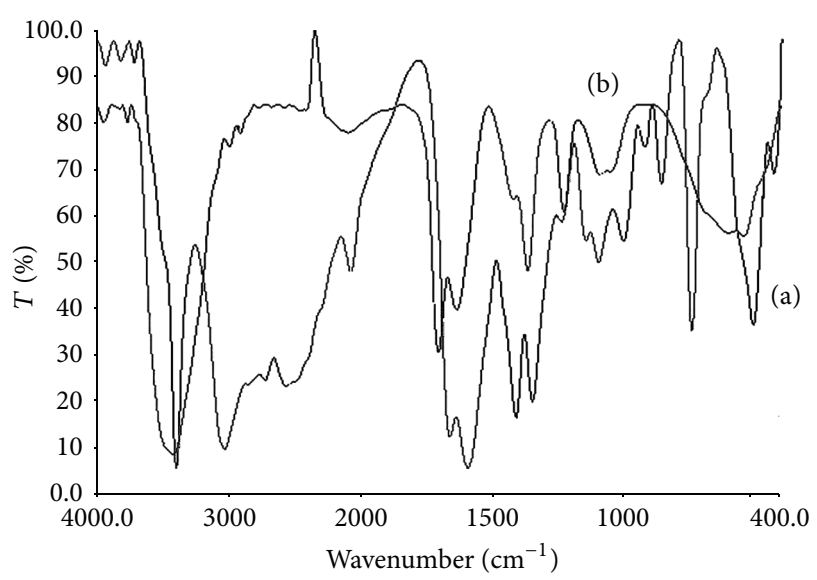

Figure 3: FTIR spectra. (a) Pure L-Arginine. (b) Film formed on the metal surface after immersion in the sea water for 1 day containing $250 \mathrm{ppm}$ of L-Arg and $25 \mathrm{ppm}$ of $\mathrm{Zn}^{2+}$.

Figure 3(b). The CN stretching frequency has shifted from 1130 to $1095 \mathrm{~cm}^{-1}$. The $\mathrm{C}=\mathrm{O}$ stretching frequency shifted from 1689 to $1630 \mathrm{~cm}^{-1}$. The $\mathrm{NH}$ stretching frequency shifted from 3290 to $3422 \mathrm{~cm}^{-1}$. This indicates that the nitrogen atom of 


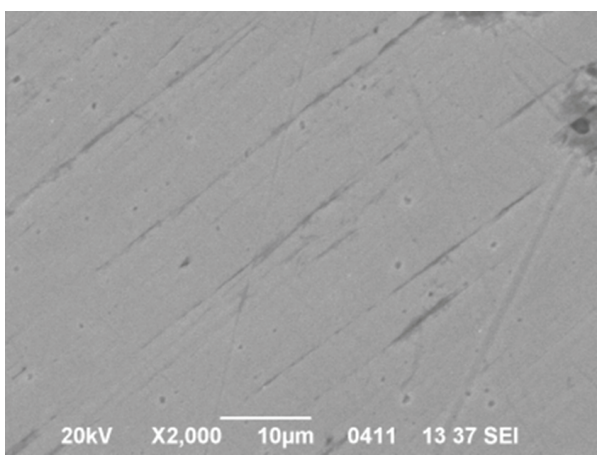

(a)

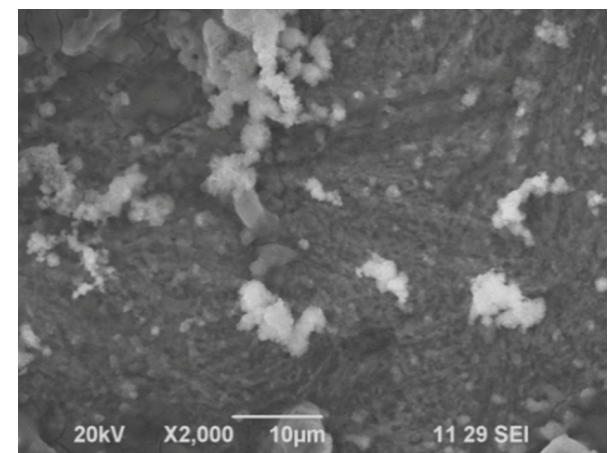

(b)

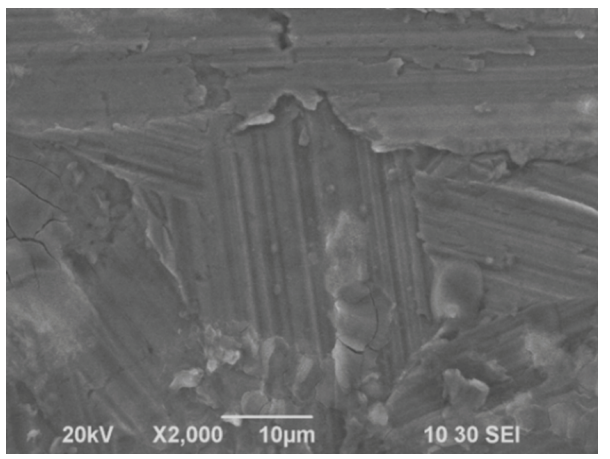

(c)

FIGURE 4: SEM micrographs of (a) carbon steel magnifications $\times 2000$ (control); (b) carbon steel immersed in sea water; magnifications $\times 2000$; and (c) carbon steel immersed in sea water containing $250 \mathrm{ppm}$ of L-Arg- $25 \mathrm{ppm}$ of $\mathrm{Zn}^{2+}$; magnifications $\times 2000$.

L-Arg has coordinated with $\mathrm{Fe}^{2+}$ formed on the metal surface resulting in the formation of $\mathrm{Fe}^{2+}$-L-Arg complex on the anodic sites of the metal surface. The peak at $1369 \mathrm{~cm}^{-1}$ is due to $\mathrm{Zn}-\mathrm{O}$ stretching. The stretching frequency due to $-\mathrm{OH}$ appears at $3105 \mathrm{~cm}^{-1}$. Thus, FITR study leads to the conclusion that the protective film consists of $\mathrm{Fe}^{2+}$-L-Arg complex and $\mathrm{Zn}(\mathrm{OH})_{2}$ on the metal surface $[29,30]$.

3.7. SEM Analysis of Metal Surface. The SEM image of magnification $(\times 2000)$ of carbon steel specimen immersed in sea water for 1 day in the absence and presence of inhibitor system is shown in Figures 4(b) and 4(c), respectively. The SEM micrographs of polished carbon steel surface (control) in Figure 4(a) image show the smooth surface of the metal. This shows the absence of any corrosion products formed on the metal surface. The SEM micrographs of carbon steel surface immersed in sea water in Figure 5(b) show the roughness of the metal surface which indicates the corrosion of carbon steel in sea water. Figure 4(c) indicates that in the presence of 250 of ppm L-Arginine and 25 of ppm $\mathrm{Zn}^{2+}$ mixture in sea water, the surface coverage increases which in turn results in the formation of insoluble complex on the surface of the metal (Arginine- $\mathrm{Zn}^{2+}$ inhibitor complex) and the surface is covered by a thin layer of inhibitors which control the dissolution of carbon steel. Such results have been reported earlier [31, 32].

3.8. Atomic Force Microscopy Characterization. Atomic force microscopy (AFM) or scanning force microscopy (SFM) is a very high-resolution type of scanning probe microscopy, with demonstrated a resolution on the order of fractions of a nanometer, more than 1000 times better than the optical diffraction limit. The three-dimensional (3D) AFM morphologies and the AFM cross-sectional profile for polished carbon steel surface (reference sample), carbon steel surface immersed in sea water (blank sample), and carbon steel surface immersed in sea water containing the formulation of $250 \mathrm{ppm}$ of L-Arginine and $25 \mathrm{ppm}$ of $\mathrm{Zn}^{2+}$ are shown in Figures (5(a), 5(b)), (5(c), 5(d)), and (5(e) and 5(f)), respectively.

Root-mean-square roughness, average roughness, and peak-to-valley value AFM image analysis was performed to obtain the average roughness $R_{a}$ (the average deviation of all points roughness profile from a mean line over the evaluation length), root-mean-square roughness, $R_{q}$ (the average of the measured height deviations taken within the evaluation length and measured from the mean line), and the maximum peak-to-valley (P-V) height values (largest single peak-tovalley height in five adjoining sampling heights). Table 7 is a summary of $\left(R_{q}\right),\left(R_{a}\right),(\mathrm{P}-\mathrm{V})$ values for carbon steel surface immersed in different environments.

Figures 5(a) and 5(d) display the surface topography of uncorroded metal surface. The values of $R_{q}, R_{a}$, and P-V height for the polished carbon steel surface (reference sample) are $4.3 \mathrm{~nm}, 3.41 \mathrm{~nm}$, and $35.28 \mathrm{~nm}$, respectively. The slight roughness observed on the polished carbon steel surface is due to atmospheric corrosion. Figures 5(b) and 5(e) display the corroded metal surface with few pits in the absence of the 


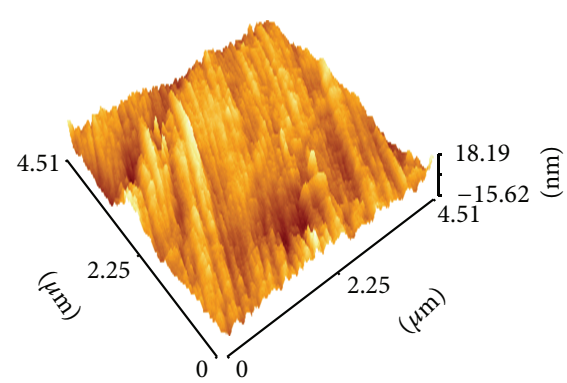

(a)
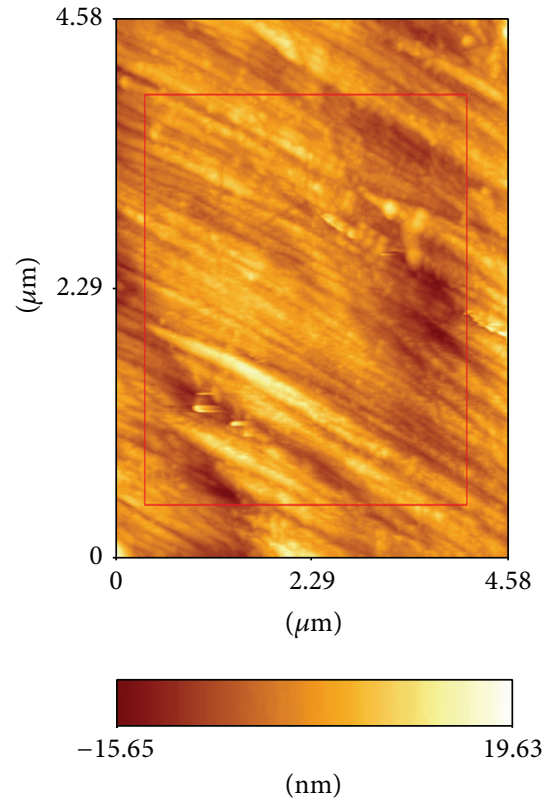

(d)

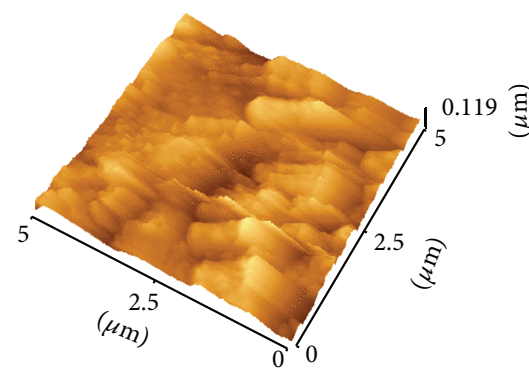

(b)

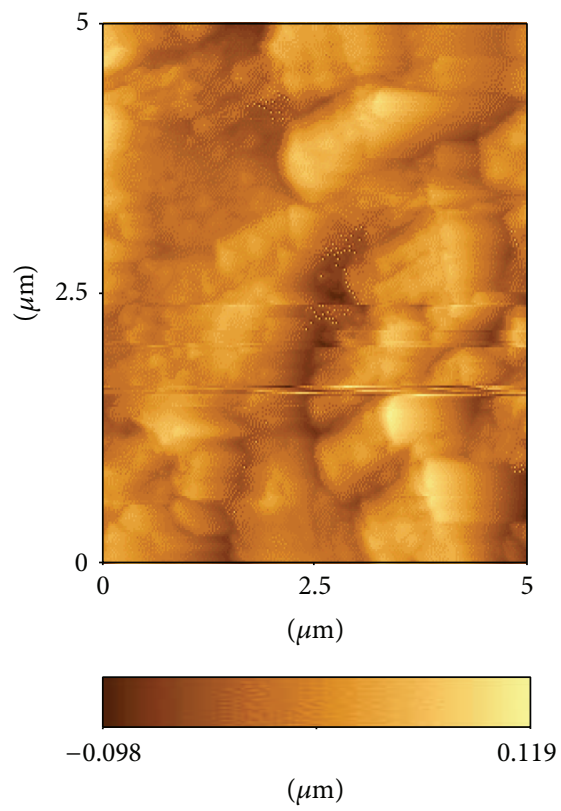

(e)

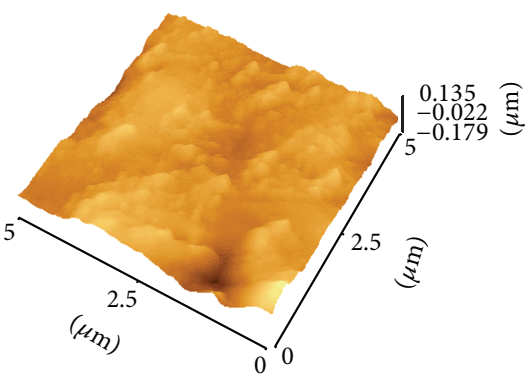

(c)
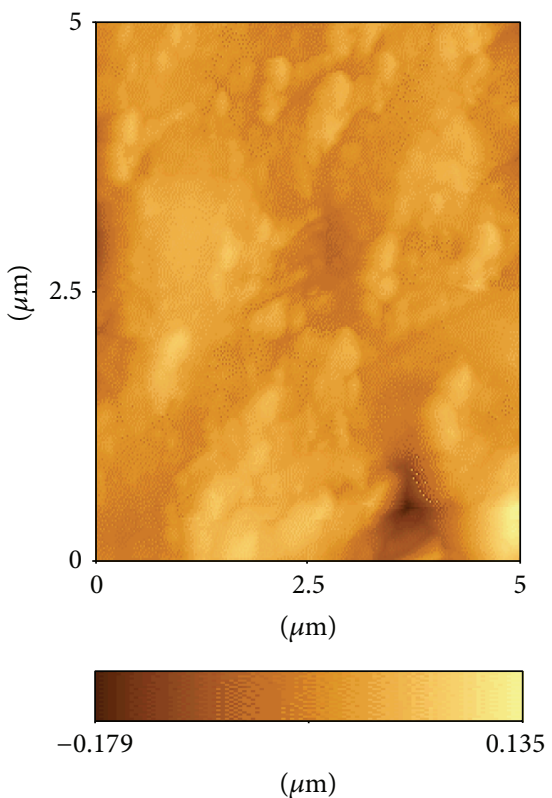

(f)

FIGURE 5: Three-dimensional AFM images of the surface of (a) polished carbon steel (control). (b) Carbon steel immersed in sea water (blank). (c) Carbon steel immersed in sea water containing L-Arg $(250 \mathrm{ppm})+\mathrm{Zn}^{2+}(25 \mathrm{ppm})$. (d) Polished carbon steel (control). (e) Carbon steel immersed in sea water (blank). (f) Carbon steel immersed in sea water containing L-Arg (250 ppm) $+\mathrm{Zn}^{2+}(25 \mathrm{ppm})$.

TABLE 7: AFM data for carbon steel surface immersed in inhibited and uninhibited environments.

\begin{tabular}{|c|c|c|c|}
\hline Sample & $\begin{array}{l}\text { RMS }(\mathrm{Rq}) \text { roughness } \\
(\mathrm{nm})\end{array}$ & $\begin{array}{l}\text { Average }(\mathrm{Ra}) \text { roughness } \\
(\mathrm{nm})\end{array}$ & $\begin{array}{c}\text { Maximum peak-to-valley height } \\
(\mathrm{nm})\end{array}$ \\
\hline (1) Polished carbon steel & 4.33 & 3.41 & 35.28 \\
\hline $\begin{array}{l}\text { (2) Carbon steel immersed in sea water } \\
\text { (blank) }\end{array}$ & 40.2 & 31.0 & 191.1 \\
\hline $\begin{array}{l}\text { (3) Carbon steel immersed in sea water } \\
+250 \mathrm{ppm} \text { of } \mathrm{L}-\mathrm{Arg}+25 \mathrm{ppm} \mathrm{Zn}^{2+}\end{array}$ & 34.4 & 25.6 & 86.02 \\
\hline
\end{tabular}

inhibitor immersed in sea water. The $\left(R_{q}\right),\left(R_{a}\right),(\mathrm{P}-\mathrm{V})$ height values for the carbon steel surface are $40.2 \mathrm{~nm}, 31.0 \mathrm{~nm}$, and $191.9 \mathrm{~nm}$, respectively. These data suggests that carbon steel surface immersed in sea water has a greater surface roughness than the polished metal surface, which shows that the unprotected carbon steel surface is rougher and was due to the corrosion of the carbon steel in the sea water environment.

Figures 5(c) and 5(f) display the steel surface after immersion in sea water containing $250 \mathrm{ppm}$ of Arginine and $25 \mathrm{ppm}$ of $\mathrm{Zn}^{2+}$. The $\left(R_{q}\right),\left(R_{a}\right),(\mathrm{P}-\mathrm{V})$ height values for the carbon steel surface are $34.4 \mathrm{~nm}, 25.6 \mathrm{~nm}$, and $86.02 \mathrm{~nm}$, respectively. The $\left(R_{q}\right),\left(R_{a}\right),(\mathrm{P}-\mathrm{V})$ height values are considerably less in the inhibited environment compared to the uninhibited environment. These parameters confirm that the surface is smoother. The smoothness of the surface is due to the formation of a compact protective film of $\mathrm{Fe}^{2+}$-L-Arginine complex and $\mathrm{Zn}(\mathrm{OH})_{2}$ on the metal surface, thereby inhibiting the corrosion of carbon steel $[33,34]$.

3.9. Cyclic Voltammetry. Cyclic voltammograms have been used to investigate the corrosion behavior of metals [35-38]. 


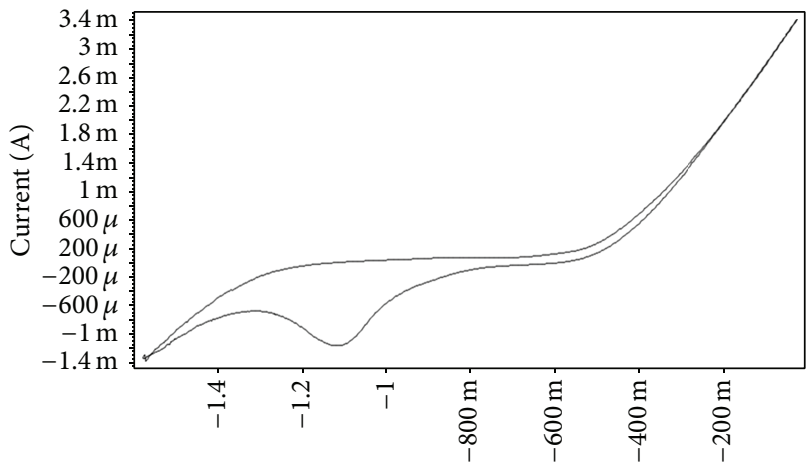

Potential (V)

(a)

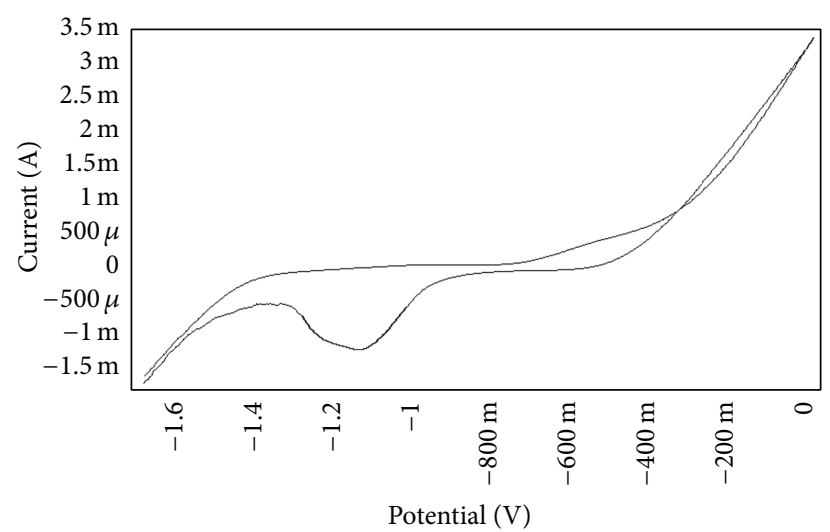

(b)

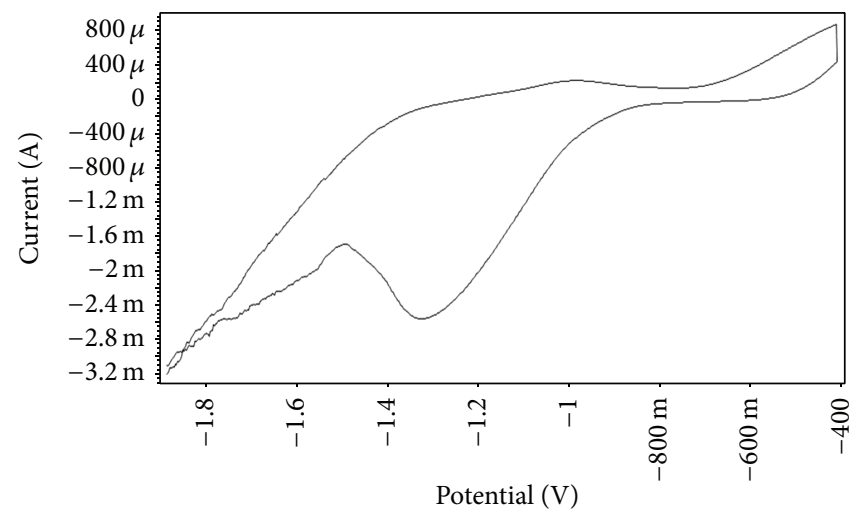

(c)

Figure 6: (a) Cyclic voltammogram of carbon steel immersed in 3.5\% $\mathrm{NaCl}$. (b) Cyclic voltammogram of carbon steel immersed in sea water for one day and (c) cyclic voltammogram of carbon steel electrode deposited with protective film.

TABLE 8: Cyclic voltammetry parameters (L-Arginine $+\mathrm{Zn}^{2+}$ ).

\begin{tabular}{lcccc}
\hline Sample & $E_{p} \mathrm{~V}$ & Peak $i_{p} \mathrm{~A}$ & Pitting corrosion product & Pitting potential \\
\hline Control (carbon steel) & -1.12 & $-1.148 \times 10^{-3}$ & - & -644.4 \\
Blank (sea water) & -1.133 & $-1.172 \times 10^{-3}$ & -500 & -755.5 \\
Inhibitor system (L-Arginine $+\mathrm{Zn}^{2+}$ ) & -1.321 & $-2.549 \times 10^{-3}$ & -490 & -580 \\
\hline
\end{tabular}

Deyab and Keera [38] have analyzed the influence of sulphide, sulphate, and bicarbonate anions on the pitting corrosion behavior of carbon steel in formation water containing chloride ions by means of cyclic voltammetry technique. The cyclic voltammograms were reworked in the presence of increasing amounts $(0.1-0.3 \mathrm{M})$ of $\mathrm{NaCl}$ at a scan rate of $10 \mathrm{mVs}^{-1}$. The anodic response exhibits a well-defined anodic peak, followed by a passive region. The anodic peak is due to the ferrous hydroxide [39]. The cathodic sweep shows two cathodic peaks; the appearance of a cathodic peak around $-1.1 \mathrm{~V}$ is due to the reduction of the corrosion product, namely, iron oxide to iron. The appearance of the cathodic peak around $-0.7 \mathrm{~V}$ is due to the reduction of pitting corrosion product precipitate on the electrode surface.

In the present study cyclic voltammograms were recorded by immersing the working electrode, mild steel, $3.5 \% \mathrm{NaCl}$ solution. The cyclic voltammogram of mild steel immersed in $3.5 \% \mathrm{NaCl}$ is shown in Figure 6(a). It is observed that during anodic scan no peak was observed. A passive state is observed. This can be explained as follows. When the metal dissolves ferrous hydroxide is formed; when the concentration of ferrous oxide at the anodic surface exceeded its solubility product, precipitation of oxide occurred on the electrode surface. When the surface is entirely covered with oxide passive film, the anodic current density does not increase indicating onset of passivation [38]. In the passive state, the $\mathrm{Cl}^{-}$ion can be adsorbed on the base metal surface in competition with $\mathrm{OH}^{-}$ions. As a result of high polarizability of the $\mathrm{Cl}^{-}$ions, the $\mathrm{Cl}^{-}$ions may adsorb preferentially [40]. The cyclic voltammetry parameters are given in Table 8 . The cathodic sweeps show only one peak at $-1.12 \mathrm{~V}$. This is due to the reduction of the corrosion product iron oxide to iron. 
The peak due to the reduction of pitting product is absent (this reveals that pitting corrosion does not take place under the given experimental conditions).

The cyclic voltammogram of mild steel, which has been immersed in sea water for one day and dried, is shown in Figure 6(b) (brown iron oxide was observed on the mild steel electrode). It is observed that during the anodic sweep no peak appears but a passive region is observed. During the cathodic sweep the peak due to reduction of pitting corrosion product appears at 528, indicating that pitting corrosion takes place. However, the peak due to reduction of corrosion product, iron oxide, appears at $-1.133 \mathrm{~V}$. The current density increases from $-1.148 \times 10^{-3} \mathrm{~A}$ to $-1.172 \times 10^{-3} \mathrm{~A}$. This indicates that when mild steel electrode is immersed in sea water for one day, a protective film of iron oxide is formed on the electrode surface. It is stable in $3.5 \% \mathrm{NaCl}$ solution. The increases in current density are explained as follows. Chloride ion is adsorbed on the passive film. The absorbed chloride ion penetrates the oxide film especially at the flaws and defects in the oxide film [41]. When the penetrated chloride ion reaches the metal surface they promote local corrosion.

When the mild steel electrode is immersed in sea water containing $250 \mathrm{ppm}$ of L-Arginine and $25 \mathrm{ppm}$ of zinc for one day, a protective film is formed. It consists of $\mathrm{Fe}^{2+}$-L-Arginine complex, $\mathrm{Zn}^{2+}$-L-Arginine complex, and $\mathrm{Zn}(\mathrm{OH})_{2}$, as revealed by FTIR spectroscopy. The cyclic voltammogram of carbon steel electrode, deposited with the above protective film, is shown in Figure 6(c). It is observed that during the anodic sweep, dissolution of metal does not take place. This indicates that the protective film is stable and compact. Electrons are not transferred from the metal surface, and a passive region is observed. During the cathodic sweep, the peak corresponding to reduction of pitting corrosion product appears at $-490 \mathrm{mV}$. However, the peak due to reduction of iron oxide to iron appears at $-1.321 \mathrm{~V}$. The current density increases from $-1.148 \times 10^{-3} \mathrm{~A}$ to $-2.549 \times 10^{-3} \mathrm{~A}$. The increase in current density may be explained as above. It is observed from Figures 1(a), 1(b), and 1(c) that the pitting potentials for the three systems are at $-644.4 \mathrm{mV},-755.5 \mathrm{mV}$, and $-580 \mathrm{mV}$, respectively. That is when carbon steel electrode is immersed in the sea water medium, the pitting potential is shifted to a more negative side (active side, i.e., $-755.5 \mathrm{mV}$ ). It accelerates corrosion because the protective film formed is porous and amorphous. When the electrode is immersed in the inhibitor medium, the pitting potential is shifted to the noble side, that is, $-580 \mathrm{mV}$. This indicates that the passive film found on the metal surface in the presence of inhibitors is compact and stable. It can withstand the attack of chloride ion present in $3.5 \mathrm{NaCl}$.

\section{Conclusions}

The present study leads to the following conclusions.

(1) The inhibition efficiency of L-Arginine- $\mathrm{Zn}^{2+}$ system in controlling corrosion of carbon steel in sea water has been evaluated by the weight-loss method.
(2) The formulation consisting of $250 \mathrm{ppm}$ of L-Arginine and $25 \mathrm{ppm}$ of $\mathrm{Zn}^{2+}$ has $91 \%$ IE. A synergistic effect exists between Arginine and $\mathrm{Zn}^{2+}$.

(3) A more stable and compact protective film formed on the metal surface. The polarization study reveals that the L-Arginine- $\mathrm{Zn}^{2+}$ system functions as an anodic inhibitor and the formulation controls the anodic reaction predominantly.

(4) AC impedance spectra reveal that protective film is formed on the metal surface.

(5) The FTIR, AFM, and SEM analysis reveals that the protective film is formed on the metal surface.

(6) Cyclic voltammetry study reveals that the protective film is more compact and stable even in a $3.5 \% \mathrm{NaCl}$ environment.

\section{Conflict of Interests}

The authors declare that there is no conflict of interests regarding the publication of this paper.

\section{References}

[1] "US Report on Corrosion Costs and Preventive Strategies in the United States," 2012, http://corrosionda.com/.

[2] K. D. Demadis, E. Mavredaki, A. Stathoulopoulou, E. Neofotistou, and C. Mantzaridis, "Industrial water systems: problems, challenges and solutions for the process industries," Desalination, vol. 213, no. 1-3, pp. 38-46, 2007.

[3] M. Behpour, S. M. Ghoreishi, A. Gandomi-Niasar, N. Soltani, and M. Salavati-Niasari, "The inhibition of mild steel corrosion in hydrochloric acid media by two Schiff base compounds," Journal of Materials Science, vol. 44, no. 10, pp. 2444-2453, 2009.

[4] G. Bereket and A. Yurt, "The inhibition effect of amino acids and hydroxy carboxylic acids on pitting corrosion of aluminum alloy 7075," Corrosion Science, vol. 43, no. 6, pp. 1179-1195, 2001.

[5] R. Manickavasagam, K. J. Karthik, M. Paramasivam, and S. V. Iyer, "Poly(styrene sulphonic acid)-doped polyaniline as an inhibitor for the corrosion of mild steel in hydrochloric acid," Anti-Corrosion Methods and Materials, vol. 49, no. 1, pp. 19-26, 2002.

[6] T. A. Aliev, "Influence of salts of alkylphenol sulfonic acid on the corrosion of St3 steel in HCl-kerosene systems," Materials Science, vol. 44, no. 5, pp. 665-671, 2008.

[7] W. A. Badawy, K. M. Ismail, and A. M. Fathi, "Corrosion control of $\mathrm{Cu}-\mathrm{Ni}$ alloys in neutral chloride solutions by amino acids," Electrochimica Acta, vol. 51, no. 20, pp. 4182-4189, 2006.

[8] M. S. Morad, "Corrosion inhibition of mild steel in sulfamic acid solution by S-containing amino acids," Journal of Applied Electrochemistry, vol. 38, no. 11, pp. 1509-1518, 2008.

[9] O. Olivares, N. V. Likhanova, B. Gómez et al., "Electrochemical and XPS studies of decylamides of $\alpha$-amino acids adsorption on carbon steel in acidic environment," Applied Surface Science, vol. 252, no. 8, pp. 2894-2909, 2006.

[10] O. Olivares-Xometl, N. V. Likhanova, M. A. DomínguezAguilar, E. Arce, H. Dorantes, and P. Arellanes-Lozada, "Synthesis and corrosion inhibition of $\alpha$-amino acids alkylamides for mild steel in acidic environment," Materials Chemistry and Physics, vol. 110, no. 2-3, pp. 344-351, 2008. 
[11] N. O. Eddy, "Experimental and theoretical studies on some amino acids and their potential activity as inhibitors for the corrosion of mild steel, part 2," Journal of Advanced Research, vol. 2, no. 1, pp. 35-47, 2011.

[12] H. Ashassi-Sorkhabi and E. Asghari, "Electrochemical corrosion behavior of Al7075 rotating disc electrode in neutral solution containing l-glutamine as a green inhibitor," Journal of Applied Electrochemistry, vol. 40, no. 3, pp. 631-637, 2010.

[13] K. F. Khaled, "Corrosion control of copper in nitric acid solutions using some amino acids-a combined experimental and theoretical study," Corrosion Science, vol. 52, no. 10, pp. 3225$3234,2010$.

[14] M. A. Abdel Rahim, H. B. Hassan, and M. W. Khalil, "Naturally Occuring Organic Substances as Corrosion Inhibitors for mild steel in acid medium: concentration and temperature effects," Materialwissenschaft und Werkstofftechnik, vol. 28, no. 4, pp. 198-204, 1997.

[15] V. Hluchan, B. L. Wheeler, and N. Hackerman, "Amino acids as corrosion inhibitors in hydrochloric acid solutions," Werkstoffe und Korrosion, vol. 39, no. 11, pp. 512-517, 1988.

[16] G. Wranglen, Introduction to Corrosion and Protection of Metals, Chapman \& Hall, London, UK, 1985.

[17] M. Manivannan and S. Rajendran, "Investcation of inhibitive action of urea- $\mathrm{Zn}^{2+}$ system in the corrosion control of carbon steel in sea water," International of Engineering Science and Technology, vol. 3, no. 11, pp. 19-23, 2011.

[18] H. T. M. Abdel-Fatah, "The inhibition action of tyrosine on the corrosion of low chromium steel in 7 wt percent sulfamic acid," Anti-Corrosion Methods and Materials, vol. 59, no. 1, pp. 23-31, 2012.

[19] V. Johnsirani, S. Rajendran, J. Sathiyabama, T. S. Muthumegala, A. Krishnaveni, and N. Hajara Beevi, "Inhibitive action of malachite green- $\mathrm{Zn}^{2+}$ system," Bulgarian Chemical Communications, vol. 44, no. 1, pp. 41-51, 2012.

[20] J. Wilson Sahayaraj, A. John Amal Raj, Susai Rajendran, and N. Vijaya, "Synergistic and antagonistic effects of sodium molybdate- $\mathrm{Zn}^{2+}$ system," E-Journal of Chemistry, vol. 9, no. 4, pp. 1746-1752, 2012.

[21] M. Sangeetha, S. Rajendran, J. Sathiyabama et al., "Corrosion inhibition by an aqueous extract of Phyllanthus amarus," Portugaliae Electrochimica Acta, vol. 29, no. 6, pp. 429-444, 2011.

[22] C. Mary anbarasi and S. Rajendran, "Inhibition of corrosion of carbon steel by heptane sulphonic acid- $\mathrm{Zn}^{2+}$ system," Journal of Electrochemical Science and Engineering, vol. 2, no. 1, pp. 1-18, 2012.

[23] H. H. Abdel Rahman, A. H. E. Moustafa, and M. K. Awad, "Potentiodynamic and quantum studies of some amino acids as corrosion inhibitors for copper," International Journal of Electrochemical Science, vol. 7, no. 2, pp. 1266-1287, 2012.

[24] Z. Zhang, G. Yan, and L. Ruan, "A study of the inhibition of iron corrosion by glutamic acid derivatives self-assembled films," Advanced Materials Research, vol. 415-417, pp. 964-967, 2012.

[25] M. Mobin, M. Parveen, and M. Z. A. Rafiquee, "Inhibition of mild steel sorrosion using L-histidine and synergistic surfactants additives," Journal of Materials Engineering and Performance, vol. 22, no. 2, pp. 548-556, 2012.

[26] P. Liu, L. Gao, and D. Zhang, "Inhibition of mixed selfassembled films of phenylalanine and tryptophan for copper corrosion," Journal of the Chinese Society of Corrosion and Protection, vol. 32, no. 2, pp. 163-167, 2012.

[27] D. Q. Zhang, H. Wu, and L. X. Gao, "Synergistic inhibition effect of l-phenylalanine and rare earth $\mathrm{Ce}(\mathrm{IV})$ ion on the corrosion of copper in hydrochloric acid solution," Materials Chemistry and Physics, vol. 133, no. 2-3, pp. 981-986, 2012.

[28] E. Hamed, S. S. Abd El-Rehim, M. F. El-Shahat, and A. M. Shaltot, "Corrosion inhibition of nickel in $\mathrm{H}_{2} \mathrm{SO}_{4}$ solution by alanine," Materials Science and Engineering B: Solid-State Materials for Advanced Technology, vol. 177, no. 5, pp. 441-448, 2012.

[29] K. Anuradha, R. Vimala, B. Narayanasamy, J. A. Selvi, and S. Rajendran, "Corrosion inhibition of carbon steel in low chloride media by an aqueous extract of Hibiscus rosa-sinensis Linn," Chemical Engineering Communications, vol. 195, no. 3, pp. 352366, 2008.

[30] S. M. A. Hosseini, M. Quanbari, and M. Salari, "Corrosion inhibition of stainless steel 347 in the mixture of phosphoric and acetic acid using phosphorus ylide compound," Indian Journal of Chemical Technology, vol. 14, no. 4, pp. 376-381, 2007.

[31] M. Mobin, M. Parveen, and M. Alam Khan, "Inhibition of mild steel corrosion using L-tryptophan and synergistic surfactant additives," Portugaliae Electrochimica Acta, vol. 29, no. 6, pp. 391-403, 2011.

[32] A. S. Sahayaraja and S. Rajendran, "Inhibition of corrosion of carbon steel in well water by arginine- $\mathrm{Zn}^{2+}$ system," Journal of Electrochemical Science and Engineering, vol. 2, no. 2, pp. 91-104, 2012.

[33] B. Shyamala Devi and S. Rajendran, "Influence of garlic extract on the inhibition efficiency of tri sodium citrate," International Journal of Chemical Science and Technology, vol. 1, pp. 79-87, 2011.

[34] B. Shyamala Devi and S. Rajendran, "Influence of henna extract on the inhibitionefficiency of diethylene triamine penta(methylenephosphonic acid) DTPMP- $\mathrm{Zn}^{2+}$ system," International Journal of Advances in Engineering, Science and Technology. In press.

[35] C. A. M. Dutra, E. N. Cadaro, and R. Z. Nakazato, "Electrochemical behavior and corrosion study of electrodeposits of $\mathrm{Zn}$ and Zn-Fe-Co on steel," Materials Science and Applications, vol. 3, no. 6, pp. 348-354, 2012.

[36] Y. Li, P. Kumar, X. Shi, T. A. Nguyen, Z. Xiao, and J. Wu, "Electroless synthesis of Ni-P and Ni-Zn-P alloy coatings for protecting steel rebar from chloride-induced corrosion," International Journal of Electrochemical Science, vol. 7, pp. 8151-8169, 2012.

[37] L. Feng, H. Yang, and F. Wang, "Experimental and theoretical studies for corrosion inhibition of carbon steel by imidazoline derivative in $5 \% \mathrm{NaCl}$ saturated $\mathrm{Ca}(\mathrm{OH})_{2}$ solution," Electrochimica Acta, vol. 58, no. 1, pp. 427-436, 2011.

[38] M. A. Deyab and S. T. Keera, "Cyclic voltammetric studies of carbon steel in chloride formation water solution and effect of some inorganic salts," Egyptian Journal of Petroleum, vol. 21, no. 1, pp. 31-36, 2012.

[39] V. K. Gouda, "Pitting behaviour of UNS NO 8904 stainless steel in salt solutions," in Proceedings of the 12th International Corrosion Congress, pp. 2011-2021, Houston, Tex, USA, 1993.

[40] S. A. M. Refaey, S. S. Abd El-Rehim, F. Taha, M. B. Saleh, and R. A. Ahmed, "Inhibition of chloride localized corrosion of mild steel by $\mathrm{PO}_{4}{ }^{3-}, \mathrm{CrO}_{4}{ }^{2-}, \mathrm{MoO}_{4}{ }^{2-}$, and $\mathrm{NO}^{2-}$ anions," Applied Surface Science, vol. 158, no. 3, pp. 190-196, 2000.

[41] D. C. W. Kannangara and B. E. Conway, "Zinc oxidation and redeposition processes in aqueous alkali and carbonate solutions. I: $\mathrm{pH}$ and carbonate ion effects in film formation and dissolution," Journal of the Electrochemical Society, vol. 134, no. 4, pp. 894-906, 1987. 

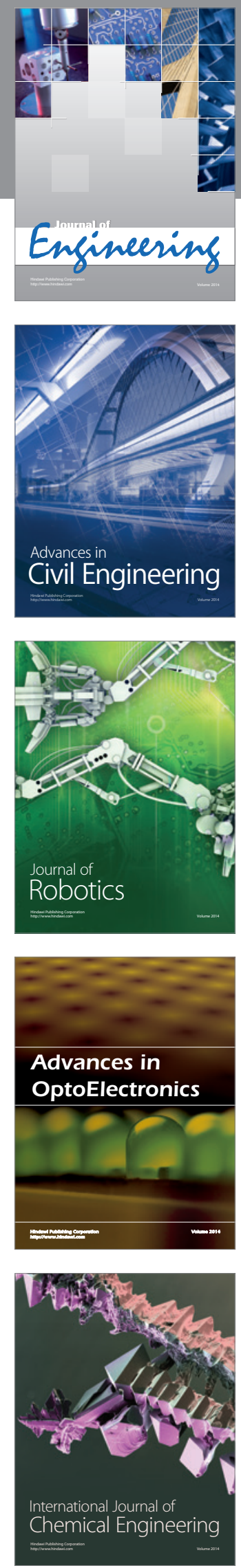

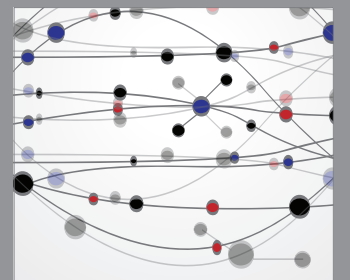

The Scientific World Journal
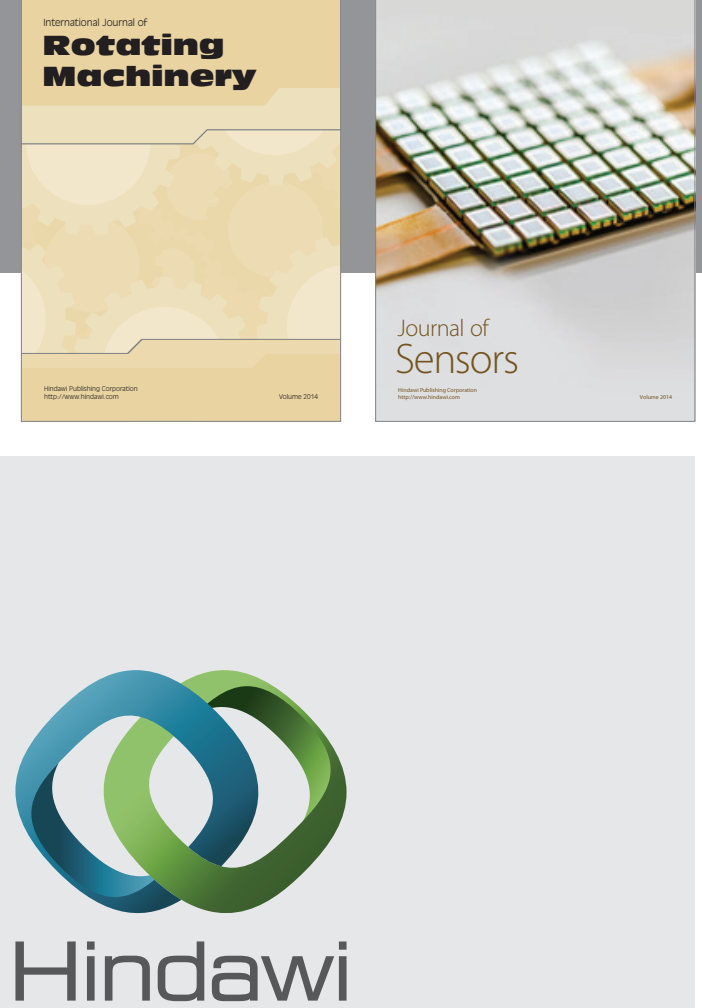

Submit your manuscripts at http://www.hindawi.com
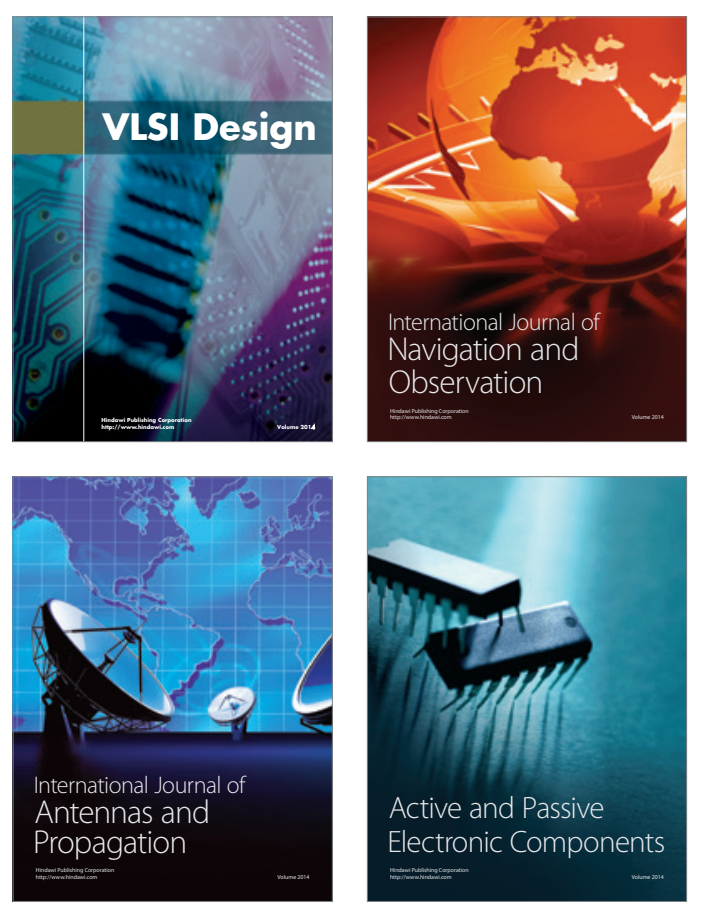
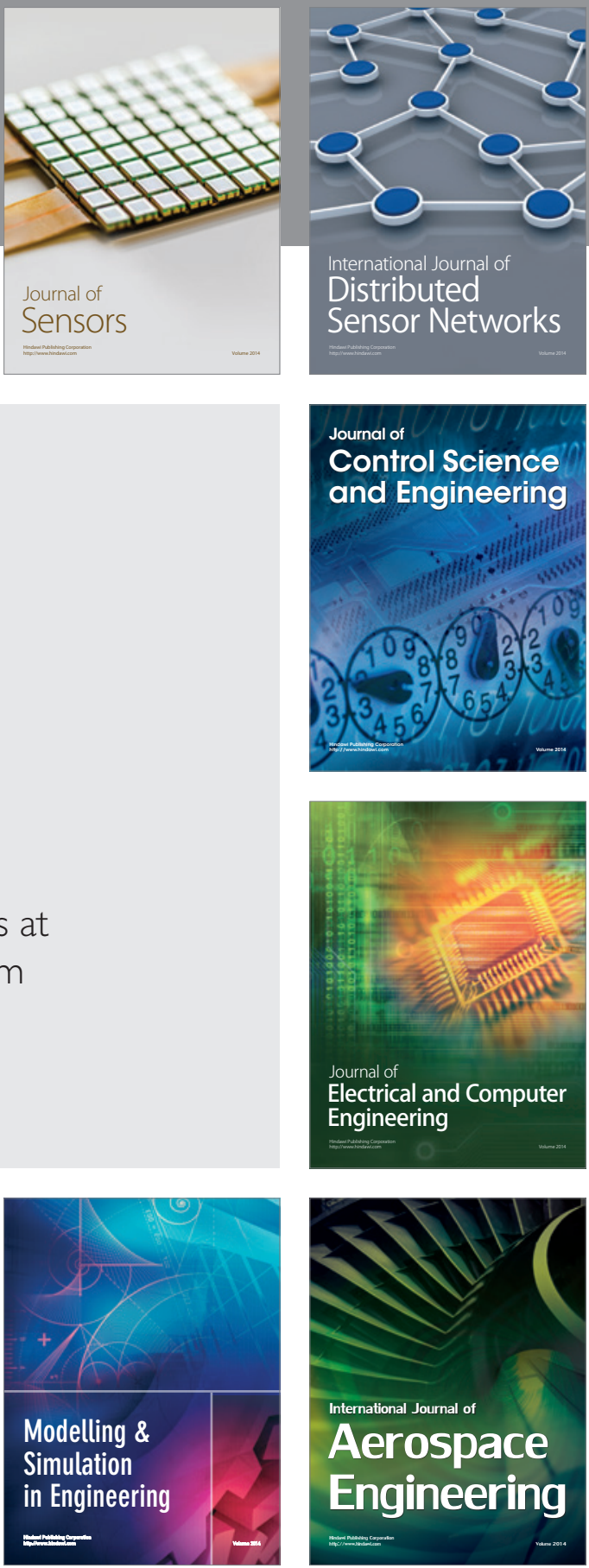

Journal of

Control Science

and Engineering
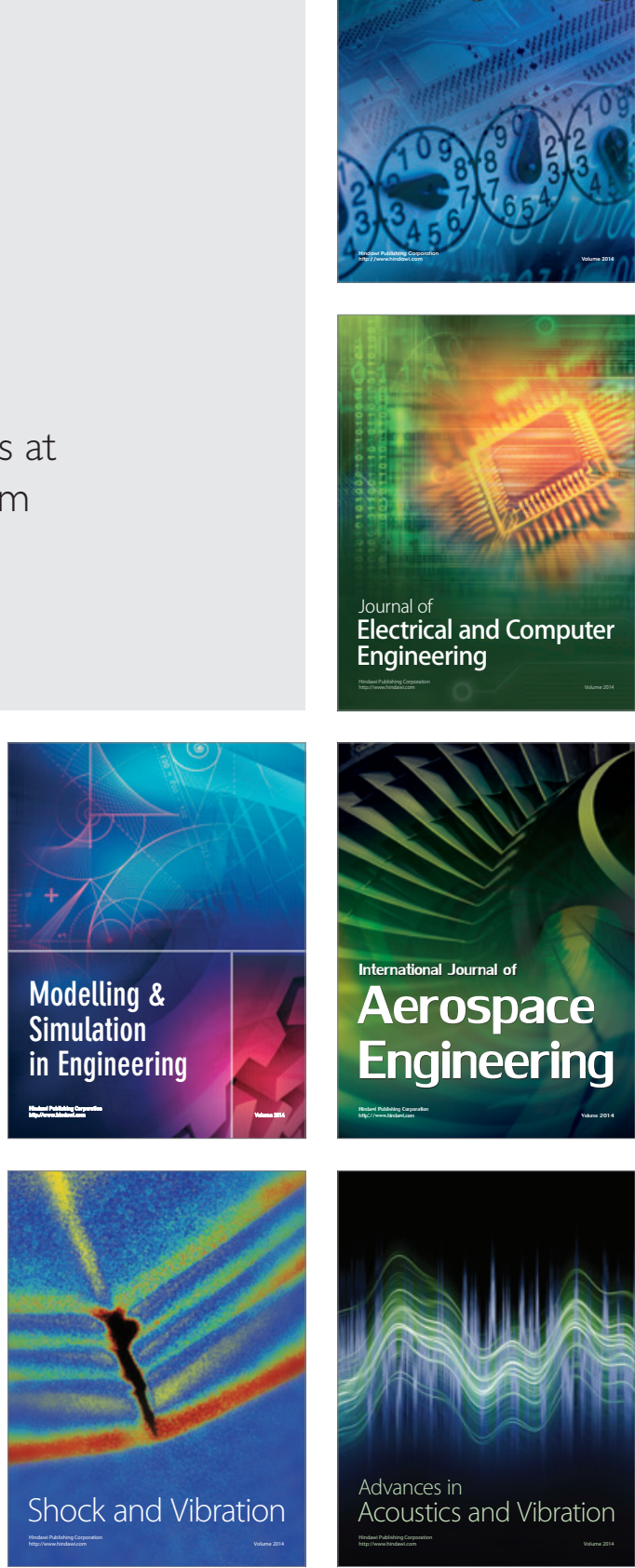